\title{
Ethics in pharmacy education: a research on pharmacy students' ethical awareness and views
}

\author{
Leyla Alaca ${ }^{1 *}$, Fulya Aydınlı Kulak ${ }^{2}$ \\ ${ }^{1}$ Faculty of Pharmacy, İstanbul University, 34116, İstanbul, Turkey \\ ${ }^{2}$ School of Business, İstanbul University, 34320, İstanbul, Turkey
}

ORCID ID of the author: F.A.K. 0000-0002-5487-6345.

Cite this article as: Alaca L, Aydınlı Kulak F (2019). Ethics in pharmacy education: a research on pharmacy students' ethical awareness and views. Istanbul J Pharm 49 (2): 70-76.

\begin{abstract}
This study was conducted to determine the ethical awareness of pharmacy students. Additionally, it intends to find the similarities and differences between ethical orientations of the pharmacy students having done the course "Pharmacy Deontology" or not. Moreover, the views and evaluations of the students who have completed the course are determined. Two hundred pharmacy students from Istanbul University Faculty of Pharmacy participated in the research. The research data was collected through questionnaires prepared by the researchers based on Deontology Charter by the Turkish Pharmacists' Association and the Pharmacies and Pharmacists Law no. 6197 and analyzed via t-test. The general results reflect a great deal of ethical awareness except the issues such as, providing prescription medicine and non-medical health products, promotional activities and use of advertisements. Moreover, there is a statistical significant difference between the two groups' of ethical orientations (participants having completed the course or not). As an overall evaluation, the pharmacy deontology course seems to add value for pharmacicst candidates to make ethical decisions.

Keywords: Ethics, pharmacy, pharmacy education, pharmacy ethics education, pharmacy deontology
\end{abstract}

\section{INTRODUCTION}

Pharmacy, as a profession, is one of the most important professions in the health care area. Patients can easily gain access to the pharmacists. Therefore, pharmacists as health professionals consulting directly with patients, who explain the use and storage of medicine, should know how to deal with the patients in a proper way. Today not only communication between patients and pharmacists is important, but also patients' rights. One of the most important topics is "ethics" in developing new programmes. Due to these developments, it is crucial for pharmacy students to get the necessary information regarding pharmaceutical ethics and it is a requirement for pharmacy students to have strong skills in replying to and dealing with the ethical dilemmas they may face during their careers. So the objective of this research is to determine the ethical awareness of the students and compare ethical awareness of the students having had the pharmacy deontology course or not. Moreover, the research intends to determine the course's effectiveness based on the course participants'views.

\section{LITERATURE REVIEW}

\section{Basic Terms: Ethics, Moral and Deontology}

The term "ethics" derives from the word "ethicos" in Greek. "Ethos" means character and tradition. Ethics, as a definition, is a philosophical system trying to explain morality and determine what is good and bad, right and wrong, virtuous and just (Rose 2008). In other words, ethics is a philosophy of moral. 
Morality involves all the restrictive rules of the society those are derived from, the difference between right and wrong, good and bad. Therefore, morality can be expressed as the required beliefs for a good life. The term morality is unique for human beings both consciously and emotionally. It distinguishes human beings from the other living things. The three basic approaches for morality involves the following (Öztürk 2006):

- Morality has a religious basis and derives from the nature of human beings.

- Morality has a philosophical basis and is based on senses.

- Morality has a society basis. That means people have to obey several rules in order to be legitimate from the side of the society.

In the literature, the terms "ethics" and "morality" are usually used interchangeably although they have differences. Firstly, ethics is the philosopy of moral whereas morality is the research subject of ethics. Secondly, morality deals with more tangible concepts. On the other hand, ethics has both tangible and intangible concepts. Finally, morality may change from person to person whereas ethics for the term "desired good" is universal.

The term "deontology" derives from the words "deontos" and "logos" in Greek. Deontos means duty, the things that ought to be done and logos means science. So deontology can be defined as the science of duty or responsibility.

Considering the rapid change in many working environments, including the health industry, there are plenty of unanswered ethical dilemmas professionals face. From the side of the pharmacy field, the pharmacists have to obey the rules in the Deontology Charter by Turkish Pharmacists' Association (date: 27.07.1968). Deontology is the information of liabilities which have several sanctions as a result of the current situation. On the other hand, ethics does not only look for the answers for the current situation, it also looks for the answers for the potential situations. Therefore, ethics and deontology complete each other. The relationship between ethics, morals and deontology is presented in Figure 1.

\section{Ethical Theories}

The history of ethics goes back to 2500 years ago and reaches back to Greek philosopher Aristoteles time. Ethical theories can be investigated in two categories namely "teleological" and "deontological" approaches.

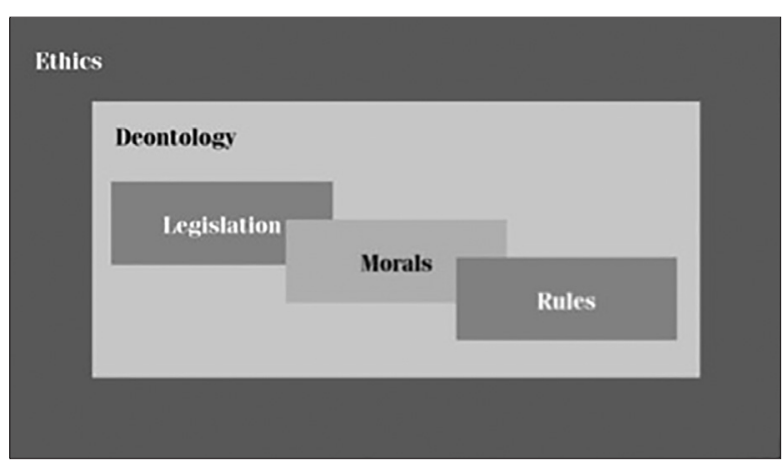

Figure 1. Relation between ethics, morals and deontology (Arda and Şahinoğlu 1995).
Teleological approach: The teleological approach primarily concerns itself with outcomes or ends since "telos" means the final purpose, issue or goal in Greek (Winstanley and Woodall 2000). According to the teleological approach, behaviors can not solely be classified as right or wrong. In order to evaluate behaviors, their results have to be evaluated. If the results are good, then the behavior is good.

A famous theory of teleological approach is utilitarianism. According to the utilitarian theory, one has a duty to calculate how much happiness various courses of action will generate, and to choose the course of action generating the most happiness (Buckley et al. 2001). In other words, utilitarianism offers the criterion of producing the greatest good for the greatest number of people (Greenwood 2002).

Deontological approach: The deontological approach involves several theories such as duty ethics, rights and justice theories. According to Kant's duty ethics, the majority of societies good can not be taken as an indicator to define behaviors as good or not (Bezci 2005). According to Kant, one must "act in such a way that you always treat humanity, whether in your own person or in the person of another, never simply as a means, but always at the same time." (Greenwood 2002)

On the other hand, rights theory involves protection of human rights on the basis of individuals or groups. Everybody has human rights and they must be treated in a respectful way (Aydın 2017).

All ethical theories intend to determine which behaviors, decisions or practices are ethical. However, they usually do not provide the same answer to the question "What is ethical?". As an overall evaluation, they provide necessary information to solve ethical concerns and dilemmas.

\section{Medical Ethical Principles}

Pharmacists are health professionals ensuring society health, prevention of diseases, delivery of medicine and support to patients to benefit from medicine. In the last two decades, the role of the pharmacy profession has inevitably changed, however the basic ethical principles are the same. These principles are being reviewed in order to define ethics in pharmacy. These principles are the guidelines for pharmacists, other health professionals, patients and society in order to ensure ethical behavior.

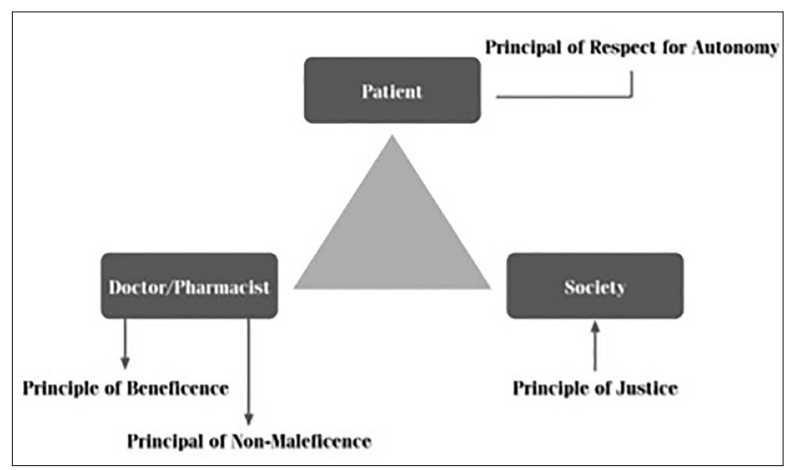

Figure 2. Relation between ethical principles (Arda and Şahinoğlu 1995). 
According to Beauchamp and Childress (1979), the basic medical ethical principles are; respect for autonomy, nonmaleficence, beneficence and justice (See Figure 2). First of all, the principle of respect for autonomy requires respectful treatment in disclosing information, ensuring understanding and voluntariness and fostering autonomous decision-making. In the health industry, it is the right of the patient to choose the treatment method, the medicine, the doctor and the pharmacy with free will after being provided with the necessary information. Additionally, according to the principle of nonmaleficence, people ought not to hurt other people mentally or physically. Beneficence reveals people ought to do and promote good. Finally, the principle of justice emphasises equal access to the good in life that every rational person values (Beauchamp and Childress 2001). Of all the four principles, justice has a crucial role in ethics for the the right to access medicine in an equal way (Özçelikay et al. 1996).

\section{Pharmacy Ethics: Ethical Concerns and Dilemmas}

Due to that, pharmacy as a field, includes ethical considerations in nature and pharmacists have to ask themselves what to do and why they should do this. So it is clear that pharmacists are directly related to deontology and ethics (Weinstein 1993).

Pharmacy ethics deals with the discussions, explanations and solutions of value concerns which pharmacists face in practice. Therefore, pharmacy ethics aims to define attitudes and behaviors of pharmacists when they face ethical dilemmas and determine the right attitudes and behaviors in specific situations (Weinstein 1993).

Ethical concerns of the pharmacists can be summarized as follows (Kuçuradi 1993):

Providing information to the patient: This concern deals with not only telling the truth, but also providing useful and supportive information.

Privacy: This is about the limits pharmacists should express information regarding the patient's situation to third parties such as doctors, other pharmacists or to anyone. Secret information provided to third parties could result with ethical concerns.

Choosing the product: In pharmacy, it is possible to have several ethical problems due to the products chosen for sale. Those problems may include, providing generic drugs, medicine with insufficient information, hand-made medicine which is not approved by the Health Ministry and selling medicine with a close expiry date.

Objectivity: Nowadays price policies implemented by offical foundations conflict with the principal of objectivity in Turkey. Additionally, there is a serious gap between retail sales prices and offical foundation prices due to the fact that producers may allow a significant discount to offical foundations. These are all against objectivity and fairness principles.

Relations with the producers: The pharmaceutical companies or the distributers may use persuasive techniques in order to make their products preferred. If the pharmacists accept promotional gifts in an exchange of medical advice or recommendations, this is a serious ethical problem.

As an overall evaluation, pharmacists usually face ethical concerns and they have to decide what the right behavior is. So ethical dilemmas which occur when there is a conflict between ethical behavior and principles can be expressed from the side of the pharmacists as follow (Asil 1991):

\section{Ethical dilemmas regarding recipes:}

- Preparing a recipe which threathens health.

- Preparing a recipe involving a medicine which is of no real value, even though the pharmacist is aware of an alternative medicine which will help.

- Suggesting the patient an alternative drug treatment if the recipe has a problem.

- Providing drug treatment without a recipe.

Ethical dilemmas regarding beliefs and values: Selling or preparing medicine against the pharmacist's own beliefs and values.

\section{Ethical dilemmas between the doctor and the pharmacist:}

- Providing the patient information regarding a diagnosis if the patient has not been provided with this information before.

- Reviewing a doctor's degree of sufficiency.

- Keeping information from the patient's knowledge due to the doctor's request.

\section{Ethical dilemmas regarding product sale:}

- Selling products with insufficient information.

- Selling habit-forming drugs.

- Selling products with no use.

- Giving someone or a group a reduction.

Ethical dilemmas regarding research ethics: Participating in research which provides low use for patients.

Ethical dilemmas regarding euthanasia: Preparing medicine for a patient regarding euthanasia and participating in the process.

Considering the above-mentioned ethical problems and dilemmas which pharmacists face in practice, ethics in pharmacy education aims to provide pharmacist candidates the required skills in determining and solving ethical problems as well as using ethical principles in a proper way. In this way, a research intending to measure pharmacy students' ethical orientations has been designed.

\section{MATERIALS AND METHODS}

\section{Objective and Scope of the Research}

This study intends to determine the ethical orientations of pharmacy students and compare the ethical awareness of the students who participated in the pharmacy deontology course and of those who did not. Additionally, participants of the course are asked to evaluate the course in several dimensions. Therefore, the other objective of the research is to determine the course's effectiveness from the student's perspective. 
The research universe consists of the pharmacy students in Turkey. Our sample is limited to the students at Istanbul University Faculty of Pharmacy. One of the reasons why Istanbul University Faculty of Pharmacy is chosen is because of the high number of students being educated there. Secondly, the Faculty is one of the oldest faculties in Turkey. Additionally, researchers could easily access the Faculty's students.

From the total number of 1.190 students in 2017, questionnaires were distributed to 250 students. As a result, 200 questionnaires were fully filled out and used for analysis, whereas the other 50 questionnaires were excluded from the research due to missing answers and sections. The grade distribution of the sample is presented in Table 1.

As mentioned before, the objective of the research involves determining the difference regarding ethical awareness between the participants who participate in the course "Pharmacy deontology" and those who did not. Therefore, it should be expressed that 110 participants participated in the course and the remaining 140 participants did not yet participate in

\section{Table 1. Grade distribution of the sample}

\begin{tabular}{|lcc|}
\hline Grades & Distributed & Collected and Analyzed \\
\hline 1 & 60 & 45 \\
2 & 40 & 30 \\
3 & 40 & 35 \\
4 & 50 & 45 \\
5 & 60 & 45 \\
Total & 250 & 200 \\
\hline
\end{tabular}

the course. The questionnaire also involves a question asking the participants if they participated in the course or not.

\section{Limitations}

This research inevitably has several limitations. Firstly, the scope of the research is limited to the students of Istanbul University, Faculty of Pharmacy. Therefore, it is not possible to generalize the results to all pharmacy students in Turkey. Secondly, as mentioned before, the participants are divided into two groups with consideration to whether they participated in the pharmacy deontology course or not. Furthermore the ethical awareness of the students in the two groups is compared. Undoubtedly, there may be several other variables such as their personalities, their families' ethical orientations, and backround, etc. affecting the ethical orientations of the students. However, it would be difficult to measure and control these variables' effects on their ethical orientations. Therefore, the differences between the two groups regarding ethical awareness are attached to whether they participated in the course or not.

\section{Data Collection Method, Validity and Reliability}

Research data has been collected through the questionnaire method. The questionnaire has been prepared by the researchers based on Deontology Charter by Turkish Pharmacists'Association and the Pharmacies and Pharmacists Law no. 6197 of 1953.

To assess content validity, 2 experts in the field of ethics and pharmacy reviewed and evaluated the items. The objective was to enhance readability, clarity and relevance of the items. Then the initial questionnaire was finally given to 10 pharmacy students who were different from the participants of the research sample to test the items. Depending on the feedback

Table 2. Ethical awareness of pharmacy students in general

\begin{tabular}{|c|c|c|c|c|c|}
\hline \multirow{2}{*}{$\begin{array}{l}\text { Items } \\
(\mathrm{N}=200)\end{array}$} & $\begin{array}{l}\text { Strongly } \\
\text { agree }\end{array}$ & Agree & $\begin{array}{l}\text { Neither disagree } \\
\text { nor agree }\end{array}$ & Disagree & $\begin{array}{l}\text { Strongly } \\
\text { disagree }\end{array}$ \\
\hline & \multicolumn{5}{|c|}{$\%$} \\
\hline $\begin{array}{l}\text { 1. I think pharmacy technicians can recommend } \\
\text { drugs to the patients. }\end{array}$ & 3.5 & 11 & 15.5 & 39 & 31 \\
\hline $\begin{array}{l}\text { 2. If it is urgent, I can deliver a prescription medicine } \\
\text { without a recipe. }\end{array}$ & 3 & 19 & 29 & 27.5 & 21.5 \\
\hline $\begin{array}{l}\text { 3. I think it is not necessary for a pharmacist to be } \\
\text { always in the pharmacy. }\end{array}$ & 8.5 & 13 & 9.5 & 39 & 30 \\
\hline $\begin{array}{l}\text { 4. I think it is unfavorable to share patients' information } \\
\text { with demanding firms and individuals (except legal cases) }\end{array}$ & 52.5 & 21 & 5.5 & 11 & 9 \\
\hline $\begin{array}{l}\text { 5. I can deliver the drugs to the patient without contacting } \\
\text { the doctor even if I am in doubt about that there is a } \\
\text { mistake in the recipe. }\end{array}$ & 3.5 & 2.5 & 4.5 & 31.5 & 43 \\
\hline $\begin{array}{l}\text { 6. It is ok for me to recommend the alternative drugs } \\
\text { because of that they are more expensive. }\end{array}$ & 6 & 12 & 24 & 35 & 26 \\
\hline $\begin{array}{l}\text { 7. In today's competitive work environment, it is possible } \\
\text { to have promotional activities in the pharmacy. }\end{array}$ & 16.5 & 35.5 & 20.5 & 18.5 & 5 \\
\hline $\begin{array}{l}\text { 8. I can recommend the patients several non-medical } \\
\text { health products other than medicine. }\end{array}$ & 18.5 & 23 & 21.5 & 28 & 9 \\
\hline $\begin{array}{l}\text { 9. It is possible to use advertisements of non-medical } \\
\text { products in the pharmacy. }\end{array}$ & 13 & 45 & 18.5 & 15 & 8.5 \\
\hline $\begin{array}{l}\text { 10. I think it is right to sell non-medical health } \\
\text { products in social media. }\end{array}$ & 2 & 13,5 & 6 & 17 & 51.5 \\
\hline
\end{tabular}


provided, the questionnaire had the final design which was applied to the participants between 01.04.2017 and 20.04.2017.

To estimate reliability, the Cronbach's alpha value has been calculated via SPSS 17. The Cronbach's al pha value is 0,868 revealing the scale exhibits good internal consistency.

\section{RESULTS}

The sample of the research consists of students from Istanbul University, Faculty of Pharmacy. Of the 200 pharmacy students participating in the research, $70 \%$ are female and $20 \%$ are younger than 20 years old. Nearly half of the participants (47 $\%$ ) would like to own a pharmacy, whereas $20 \%$ would like to work in pharmaceutical companies, $16 \%$ would like to work in hospitals and $12 \%$ would like to have an academic career in the future.
The findings of the research will be presented under three titles. These are the ethical awareness of the students in general, similarities and differences regarding ethical orientations between the two groups, and views and evaluations of the students who have the pharmacy deontology course.

\section{Ethical awareness of the pharmacy students in general}

First of all, findings regarding ethical awareness of the participants, regardless of whether they have done the pharmacy deontology course or not, are presented in Table 2.

Findings regarding several items (items $1,3,4,5,6,10$ ) reflect a great deal of ethical awareness whereas ethical awareness is generally low in providing prescription medicine and nonmedical health products, promotional activities and the use of advertisements.

\section{Table 3. T-test results indicating the similaritites and differences of the two groups' ethical awareness item by item}

\begin{tabular}{|c|c|c|c|c|c|c|}
\hline Pharmacy deontology course & $\mathrm{N}$ & $\bar{x}$ & Ss & $\mathrm{T}$ & Sd & $\mathrm{p}$ \\
\hline Item 1 & \multicolumn{6}{|c|}{ "I think pharmacy technicians can recommend drugs to the patients." } \\
\hline Yes & 90 & 2.16 & 0.982 & 0.112 & 197.973 & 0.911 \\
\hline No & 110 & 2.17 & 1.188 & & & No sig. difference \\
\hline Item 2 & \multicolumn{6}{|c|}{ "If it is urgent, I can deliver a prescription medicine without a recipe." } \\
\hline Yes & 90 & 2.46 & 1.172 & 1.195 & 198 & 0.234 \\
\hline No & 110 & 2.65 & 1.072 & & & No sig. difference \\
\hline Item 3 & \multicolumn{6}{|c|}{ "I think it is not necessary for a pharmacist to be always in the pharmacy." } \\
\hline Yes & 90 & 2.56 & 1.126 & 3.086 & 197.382 & 0.002 \\
\hline No & 110 & 2.03 & 1.303 & & & Sig. difference $p<0,05$ \\
\hline Item 4 & \multicolumn{6}{|c|}{$\begin{array}{c}\text { "I think it is unfavorable to share patients' information with demanding firms and } \\
\text { individuals (except legal cases)." }\end{array}$} \\
\hline Yes & 90 & 3.94 & 1.328 & 0.716 & 198 & 0.475 \\
\hline No & 110 & 4.08 & 1.377 & & & No sig. difference \\
\hline Item 5 & \multicolumn{6}{|c|}{$\begin{array}{c}\text { "I can deliver the drugs to the patient without contacting the doctor even if I am in } \\
\text { doubt about that there is a mistake in the recipe." }\end{array}$} \\
\hline Yes & 90 & 1.97 & 1.136 & -3.088 & 198 & 0.002 \\
\hline No & 110 & 1.54 & 0.831 & & & Sig. difference $p<0,05$ \\
\hline Item 6 & \multicolumn{6}{|c|}{ "It is ok for me to recommend the alternative drugs even if they are more expensive." } \\
\hline Yes & 90 & 2.47 & 1.210 & -0.388 & 198 & 0.698 \\
\hline No & 110 & 2.40 & 1.205 & & & No sig. difference \\
\hline Item 7 & \multicolumn{6}{|c|}{$\begin{array}{c}\text { "In today's competitive work environment, it is possible to have promotional activities in } \\
\text { the pharmacy." }\end{array}$} \\
\hline Yes & 90 & 3.61 & 1.154 & 2.871 & 198 & 0.005 \\
\hline No & 110 & 3.17 & 1.154 & & & Sig. difference $p<0,05$ \\
\hline Item 8 & \multicolumn{6}{|c|}{$\begin{array}{c}\text { "I can recommend the patients several non-medical health products other than } \\
\text { medicine." }\end{array}$} \\
\hline Yes & 90 & 2.45 & 1.178 & -5.408 & 191.149 & 0.00 \\
\hline No & 110 & 3.34 & 1.163 & & & Sig. difference $p<0,05$ \\
\hline Item 9 & \multicolumn{6}{|c|}{ "It is possible to use advertisements of non-medical products in the pharmacy." } \\
\hline Yes & 90 & 3.30 & 1.240 & 0.498 & 198 & 0.619 \\
\hline No & 110 & 3.38 & 1.084 & & & No sig. difference \\
\hline Item 10 & \multicolumn{6}{|c|}{ "I think it is right to sell non-medical health products in social media." } \\
\hline Yes & 90 & 1.78 & 1.139 & -0.790 & 198 & 0.430 \\
\hline No & 110 & 1.65 & 1.062 & & & No sig. difference \\
\hline
\end{tabular}


Table 4. General t-test results indicating the difference between the two groups

\begin{tabular}{|lcccccc|}
\hline Pharmacy deontology course & N & $\bar{x}$ & Ss & T & Sd & p \\
\hline Yes & 90 & 2.55 & 0.440 & 0.104 & 198 & 0.001 \\
No & 110 & 2.54 & 0.445 & & Sig. Difference $p<0.05$ \\
Total & 200 & & & & \\
\hline
\end{tabular}

Table 5. Ethical awareness of pharmacy students in general

\begin{tabular}{|c|c|c|c|c|c|}
\hline \multirow{2}{*}{$\begin{array}{l}\text { Items } \\
(\mathrm{N}=90)\end{array}$} & $\begin{array}{l}\text { Strongly } \\
\text { agree }\end{array}$ & Agree & $\begin{array}{l}\text { Neither disagree } \\
\text { nor agree }\end{array}$ & Disagree & $\begin{array}{l}\text { Strongly } \\
\text { disagree }\end{array}$ \\
\hline & \multicolumn{5}{|c|}{$\%$} \\
\hline $\begin{array}{l}\text { Pharmacy deontology course is necessary in pharmacy } \\
\text { education. }\end{array}$ & 50 & 43.3 & 3.3 & 1.1 & 2.2 \\
\hline Ethical rules are crucial in pharmacy. & 53.3 & 43.3 & 1 & 1.1 & 1.1 \\
\hline Time devoted for pharmacy deontology course is sufficient. & 31.1 & 51.1 & 10 & 2.2 & 5.5 \\
\hline $\begin{array}{l}\text { The lecturer of pharmacy deontology course ought to be } \\
\text { an expert in this area. }\end{array}$ & 53.3 & 33.3 & 4.4 & 1.1 & 4.4 \\
\hline Pharmacy deontology course is an effective course. & 31.1 & 38.8 & 20 & 7.7 & 2.2 \\
\hline $\begin{array}{l}\text { The information provided in pharmacy deontology course } \\
\text { is useful in practice. }\end{array}$ & 33.3 & 46.6 & 7.7 & 0 & 4.4 \\
\hline $\begin{array}{l}\text { Information regarding ethics in pharmancy adds value to } \\
\text { pharmacy profession. }\end{array}$ & 41.1 & 48.8 & 5.5 & 2.2 & 2.2 \\
\hline
\end{tabular}

\section{Similarities and differences regarding ethical orienta- tions between the two groups}

Secondly, the findings on ethical awareness indicating the difference between the participants who have done the course and who have not got the course yet are presented item by item in Table 3.

Examining the findings in Table 3: First of all it is seen that there is a statistical significant difference between the two groups (the participants having the course or not) regarding the pharmacists' presence in the pharmacy (See item 3 in Table 3). According to Article 35 of the Pharmacies and Pharmacists Law no. 6197, the pharmacists ought to be always in the pharmacy. However, awareness regarding this article is low in the participants who have not done the course, whereas the participants of the course have a greater awareness regarding the issue indicating the effectiveness of the pharmacy deontology course.

Secondly, there is a significant difference between the two groups in what they ought to do when there seems to be a mistake in the recipe. According to Article 24 of the Pharmacies and Pharmacists Law no. 6197, the pharmacists ought to contact the doctor when they think that there is a mistake in the recipe (See item 5 in Table 3). On the other hand, awareness of the participants without having the course is lower than the other group.

Finally, the two groups' ethical awareness related to promotional activities and recommending the patients non-medical health products statistically diverge (See items 7 and 8 in Table 3). The participants of the course are more aware of the regulations in Deontology Charter by Turkish Pharmacists' Association (Articles 5 and 8) whereas awareness of the other group limited.
Overall, above mentioned findings reveal statistical differences between the two groups' ethical awareness when examined item by item. On the other hand, the research also investigated if there is a difference between the two groups' (participated in the course or did not) ethical awareness as a whole. The results can be seen in Table 4.

The findings in Table 4 indicate a statistical significant difference between the two groups' ethical awareness. Therefore we can conclude that the pharmacy deontology course adds value to pharmacy students' ethical orientations and awareness.

Views and evaluations of the students who have pharmacy deontology course

Finally, the views and evaluations of the pharmacy students who participated in the pharmacy deontology course are investigated in the research. The findings regarding this issue are presented in Table 5.

Depending on the findings, we can say that students who have participated in the pharmacy deontology course generally have positive views and evaluations regarding the course. On the other hand, $29 \%$ of the participants can not express that the course is effective.

\section{CONCLUSION}

Today patients' rights are heavily regarded and valued and the nature of the relationship between health professionals and the patients has heavily changed. Due to these developments, there seems to be a problematic environment in terms of trust and peace between the parties. Therefore, ethical principles and rules are required to ensure a trustful and peaceful environment. 
Pharmacists, just like the other health professionals, face ethical concerns in practice and they have to respond to these ethical concerns and dilemmas in a proper way. Undoubtedly, ethical orientations in pharmacy education will help and support pharmacist candidates to make ethical decisions.

This study intends to determine ethical awareness of pharmacy students and to compare the ethical orientations of the students who participated in and who did not participate in the pharmacy deontology course. Additionally, the course participants' views and evaluations regarding the course are presented. Depending on the research results, we can say that general ethical awareness of the pharmacy students is quite high. On the other hand, the most problematic issues are providing prescription medicine without a recipe, recommending non-medical health products, promotional activities and the use of advertisements in general.

The presence of the pharmacy deontology course seems to be benefical to make students aware that the pharmacists ought to be in the pharmacy consistently, contacting the doctor with any medical enquiries or suspicions. The course also helps to create awareness around promotional activities as well as recommending non-medical health products other than medicine that are deemed unethical.

As an overall evaluation, the pharmacy deontology course is benefical for pharmacist candidates and the findings in this study support the presence of this course in the cirriculum. In other words, universities strengthen their pharmacy cirriculum when using the pharmacy deontology course.

It was emphasized that this study inevitably has limitations. Considering the current limitations of this research, the scope of the study may be expanded to several other universities' with pharmacy courses. Thus, it will be possible to make comparisons between the ethical awareness of different universities' pharmacy students. Other limitations and variables involved in the current research, that may affect ethical orientations of students include their families' ethical orientations and their backrounds which can be controlled in future research.

Peer-review: Externally peer-reviewed.

Author Contributions: Concept - F.A.K., L.A.; Design - F.A.K., L.A.; Supervision - F.A.K.; Resource - L.A.; Materials - L.A.; Data Collection and/or Processing - L.A.; Analysis and/or Interpretation - F.A.K., L.A.; Literature Search - F.A.K., L.A.; Writing - F.A.K.; Critical Reviews - F.A.K.
Acknowledgements: This study was part of Leyla Alaca's master thesis is entitled "Ethics in Pharmacy Education: A Research on Pharmacy Students'Ethical Awareness and Views".

Conflict of Interest: The authors have no conflict of interest to declare.

Financial Disclosure: The authors declared that this study has received no financial support.

\section{REFERENCES}

- $\quad$ Arda B, Şahinoğlu PS (1995). Tıbbi etik: Tanımı, içeriği, yöntemi ve başlıca konuları. Ankara Tıp Mecmuası 3: 323-336.

- Asil E (1991). Eczacılıkta Karşılaşılan Etik Sorunlar. Eczacı Odası Yayınları, Meslek içi Eğitim Programı MiEP.

- $\quad$ Aydın M (2017). Iş/Meslek ahlâkı ve ahlak teorileri. In: Meslek etiği. Ondokuz Mayıs Üniversitesi Uzakta Eğitim Merkezi Yayınları 8: 9.

- Beauchamp, TL, Childress, JF (1979). Principles of biomedical ethics. New York: Oxford University Press.

- Beauchamp, TL, Childress, JF (2001). Principles of biomedical ethics. New York: Oxford University Press.

- $\quad$ Bezci B (2005). Kant ve Hegel'in Felsefesinde Etik Anlayışı. SÜ IIIBF Sosyal ve Ekonomik Araştırmalar Dergisi 9: 49-61.

- Buckley, MR, Danielle SB, Dwight DF, Howard JL, Howard B, Mobbs TA, Ferris GR (2001). Ethical issues in human resources systems. Human Resource Management Review 11: 11-29. [CrossRef]

Greenwood, M.R. (2002). Ethics and HRM: A review and conceptual analysis. Journal of Business Ethics 36: 261-278. [CrossRef]

- $\quad$ Özçelikay G, Şar S, Özcömert GH, Asil E (1996). Eczacılık hizmetleri ve etik. Türkiye Klinikleri Tibbi Etik Dergisi 2: 52-54.

- Kuçuradi I (1993). Sağlık bilimlerinde ve uygulamalarında etik sorunlar. Toplum ve Hekim Dergisi 57: 26-29.

- $\quad$ Öztürk O (2006). Ahlak Olgusunun Kaynağı Nedir? Köprü Dergisi 95 http://www.koprudergisi.com/index.asp?Bolum=EskiSayilar\&Gos ter=Yazi\&YaziNo=793

- $\quad$ Rose A (2008). Ethics and human resource management. In Exploring Human Resource Management, Porter C, Bingham C, Simmonds D, Mc Graw-Hill Higher Education, London.

- Weinstein BD (1993) Ethical decision making in pharmacy. American Pharmacy 9: 48-50. [CrossRef]

- Winstaley D, Woodall J (2000). The adolescence of ethics in human resource management. Human Resource Management Journal 10: 45-48. [CrossRef]

- Yıldırım G, Kadıoğlu S (2007). Etik ve temel kavramlar. C.Ü. Tıp Fakültesi Dergisi 29: 7-12.

- Deontology Charter by Turkish Pharmacists' Association. http:// www.ttb.org.tr/mevzuat/index.php?option=com_content\&view =article\&id=52:tibbdeontolojt\&catid=4:t\&ltemid=31

Pharmacies and Pharmacists Law no. 6197. http://www.mevzuat. gov.tr/MevzuatMetin/1.3.6197.pdf 